\title{
Field Evaluation of the Strategies of Integration of Fungicides and Bio Control Agents for Efficient Management of Rice Stem Rot Disease
}

\author{
Atla Ranga Rani ${ }^{1 *}$, C.P.D. Rajan ${ }^{2}$, R. Sarada Jayalakshmi Devi ${ }^{1}$, \\ V. Lakshmi Narayana Reddy ${ }^{3}$ and P. Sudhakar ${ }^{4}$ \\ ${ }^{1}$ Department of Plant Pathology, ${ }^{3}$ Department of Genetics and Plant Breeding, ${ }^{4}$ Department \\ of Crop Physiology, S.V. Agricultural College, Tirupati, 517502, India \\ ${ }^{2}$ Agricultural Research Station, Nellore, ANGRAU, Andhra Pradesh, India
}

*Corresponding author

\begin{tabular}{|c|c|}
\hline & $\begin{array}{l}A B S T \\
A\end{array}$ \\
\hline $\begin{array}{l}\text { K e y w o r d s } \\
\text { Integration } \\
\text { strategies, } \\
\text { Fungicides, } \\
\text { Antagonist, } \\
\text { S. oryzae, Rice, } \\
\text { Stem rot }\end{array}$ & \multirow{3}{*}{$\begin{array}{l}\text { Stem rot of rice, caused by Sclerotia oryzae is a serious threat to rice production in India. } \\
\text { Fungicides only provide limited control of this pathogen but also have ill effects on the } \\
\text { environment. In an attempt to develop better integrated strategies for management of this } \\
\text { disease, a field study was conducted during rabi } 2017-18 \text { to evaluate the strategies of } \\
\text { integration of effective fungicide Hexaconazole }(0.2 \%) \text { and the bacterial antagonistic } \\
\text { isolate P.F- } 4 \text { which were effective against } S \text {. oryzae in vitro studies. Among the seven } \\
\text { stratagies, the following integration strategies were statistically superior in managing the } \\
\text { stem rot disease, Alternate sprays with Hexaconazole and P.F- } 4 \text { (40.00 PDI, } 7.56 \mathrm{t} / \mathrm{ha} \text { grain } \\
\text { yield and } 10.26 \mathrm{t} / \text { ha straw yield) which was statistically at par with Seedling dip with P.F- } 4 \\
\text { and two sprays followed by two sprays with Hexaconazole ( } 44.40 \text { PDI, } 6.95 \mathrm{t} / \text { ha grain } \\
\text { yield and } 8.53 \mathrm{t} \text { /ha straw yield) and Two sprays with Hexaconazole followed by two } \\
\text { sprays with P.F- } 4 \text { ( } 48.35 \text { PDI, } 7.37 \mathrm{t} / \text { ha grain yield and } 7.73 \mathrm{t} / \mathrm{ha} \text { straw yield). While in } \\
\text { Untreated control significantly higher stem rot disease was recorded with } 67.83 \text { PDI when } \\
\text { compared with all other treatments. }\end{array}$} \\
\hline Article Info & \\
\hline $\begin{array}{l}\text { Accepted: } \\
\text { 26 June } 2018 \\
\text { Available Online: } \\
\text { 10 July } 2018\end{array}$ & \\
\hline
\end{tabular}

\section{Introduction}

Rice (Oryzae sativa L.) is one of the important staple food crops for more than 60 per cent of the world's population. Globally rice occupied an area of about 159.80 million hectares with 740.96 million tonnes of production and productivity of 4.63 metric tonnes per hectare (Directorate of Economics and Statistics, 2016). Various biotic and abiotic stress cause immense loss to rice crop wherever the crop is grown. Due to apparent changes in climatic conditions and change of genotypes and cultivation practices the profile of diseases on rice has changed over a period of time. Stem rot of rice caused by Sclerotium oryzae Catt.(Magnaporthe salvinii (Catt.) is one of the major constraints for rice production in the Indian subcontinent especially in Haryana (Singh et al., 2002). The pathogen has been reported to cause substantial losses in grain yield ranging from 5-80 per cent (Kumar et al., 2003). It was considered desirable to evaluate the efficacy of some chemical 
fungicides against the disease. Efficacy of bacterial biocontrol antagonists has been reported by Elangovan and Gnanamanickam (1992); and Sakthivel et al., (1988). But biocontrol agents alone cannot manage the disease completely when infection is already established in huge amounts in the field. Therefore, farmers favoured fungicides for managing the disease. Fungicides are deleterious to the environment and also harmful for the soil productivity and human and animal health. Due to the disadvantages of fungicides, integrated disease management programs are applied, in which judicious and recommended use of fungicides and their integration with biocontrol agents is favoured. Hence, the present investigation was carried to evaluate the strategies of integration of effective fungicide and the bio control agent for efficient management of rice stem rot disease.

\section{Materials and Methods}

A field experiment was conducted in randomized complete block design (RBD) at the experimental fields of Agricultural Research Station, Nellore, Andhrapradesh during rabi 2017-18. A popular rice variety MTU 1010 which was susceptible to stem rot diseases was transplanted with a spacing of 15 $\mathrm{x} 15 \mathrm{~cm}$ in a gross plot size of $13.455 \mathrm{sq} \mathrm{m}$. A check plot was also maintained. The root dipping of the nursery was done in the suspension of the respective bacterial isolate before transplanting. The bacterial isolate P.F4 was sprayed at concentration of $10^{6} \mathrm{CFU} / \mathrm{ml}$ of suspension. Hexaconazole was sprayed at the $0.2 \%$ concentration.

\section{Disease assessment and statistical analysis}

Fifteen days after the each spray of fungicide and bio agent disease assessment was carried out. Disease severity was measured based on 0-9 scale (SES, IRRI, 2013). Further, the scored data was converted into per cent disease index (PDI) using formula given below. The data on disease severity and yield parameters were subjected to appropriate statistical analysis.

PDI $=[($ Sum of the scores) $/$ (Number of Observation $X$ Highest Number in Rating Scale)] x 100

\section{Results and Discussion}

Stem rot disease of rice is a soil borne disease and causes crop damage from tillering stage to till harvest of the crop. Several reports are available on chemical and biological method of disease management under field condition (Phurailatpam et al., 2014; Gopika et al., 2016). Results of the study presented in table 1 and 2 revealed that, at 15 days after the first spraying, T4 (Seedling dip with P.F-4 and two sprays followed by two sprays with Hexaconazole) showed lowest per cent disease index (PDI) of 16.00 which was closely followed by T5 (Alternate sprays with Hexaconazole and P.F-4; 17.00 PDI), T1 (Hexaconazole; 18.00 PDI) and T6 (Alternate sprays with P.F-4 and Hexaconazole; 20.00 PDI). These treatments were significantly at par with each other with regard to PDI. The untreated control (T8) with 30.00 PDI which was statistically at par with the treatments $\mathrm{T} 2$ (Seedling dip with Pseudomonas fluorescens (P.F-4) and foliar spray; 27.00 PDI) and T7 (Seedling dip with P.F-4 followed by mixed spray of Hexaconazole and P.F-4; 25.00 PDI). The treatment T3 (Two sprays with hexaconazole followed by two sprays with P.F-4) with 22.00 PDI was found to be at par with all the treatments except untreated control (T8) and T4 (Seedling dip with P.F-4 and two sprays followed by two sprays with hexaconazole) treatments.

At 15 days after the second spraying, lowest per cent disease index (PDI) was observed in 
T5 (Alternate sprays with Hexaconazole and P.F-4; 21.47 PDI) which was at par with the treatments T1 (Hexaconazole; 22.78 PDI), T6 (Alternate sprays with P.F-4 and Hexaconazole; 24.00 PDI).The untreated control (T8) with 40.00 PDI which showed significantly higher stem rot disease when compared to all other treatments. Stem rot PDI in treatments $\mathrm{T} 3, \mathrm{~T} 4, \mathrm{~T} 7$ and $\mathrm{T} 2$ ranged from 28.53 to 34.00 were found to be at par among themselves. This indicated that all these treatments have almost equal efficacy against stem rot disease. At 15 days after the third spraying, lowest per cent disease index (PDI) of 30.00 was observed in T5 (Alternate sprays with Hexaconazole and P.F-4) which was at par with the treatments T1 (Hexaconazole; 32.00 PDI), T6 (Alternate sprays with P.F-4 and Hexaconazole; 33.45 PDI), T4 (Seedling dip with P.F-4 and two sprays followed by two sprays with Hexaconazole; 35.49) and T3 (Two sprays with Hexaconazole followed by two sprays with P.F-4; $36.00 \quad$ PDI).

Table.1 Field Evaluation of the strategies of integration of fungicide and biocontrol agent for efficient management of rice stem rot disease during Rabi 2017-18

\begin{tabular}{|c|c|c|c|c|c|}
\hline \multirow[t]{2}{*}{ S.No } & \multirow[t]{2}{*}{ Treatments } & \multicolumn{4}{|c|}{ Percent disease index (PDI) } \\
\hline & & $\begin{array}{l}15 \text { Days } \\
\text { after } 1^{\text {st }} \\
\text { spray }\end{array}$ & $\begin{array}{l}15 \text { Days } \\
\text { after } 2^{\text {nd }} \\
\text { spray }\end{array}$ & $\begin{array}{l}15 \text { Days } \\
\text { after } 3^{\text {rd }} \\
\text { spray }\end{array}$ & $\begin{array}{l}15 \text { Days } \\
\text { after } 4^{\text {th }} \\
\text { spray }\end{array}$ \\
\hline T1 & Hexaconazole & $\begin{array}{c}18.00 \\
(25.08)^{\mathrm{de}}\end{array}$ & $\begin{array}{c}22.78 \\
(28.49)^{\mathrm{d}}\end{array}$ & $\begin{array}{c}32.00 \\
(34.42)^{\mathrm{d}}\end{array}$ & $\begin{array}{c}49.93 \\
(44.96)^{\mathrm{bc}}\end{array}$ \\
\hline T2 & $\begin{array}{l}\text { Seedling dip with Pseudomonas } \\
\text { fluorescens (P.F-4)and foliar } \\
\text { spray }\end{array}$ & $\begin{array}{c}27.00 \\
(31.26)^{\mathrm{ab}}\end{array}$ & $\begin{array}{c}34.00 \\
(35.66)^{\mathrm{b}}\end{array}$ & $\begin{array}{c}44.36 \\
(41.75)^{\mathrm{ab}}\end{array}$ & $\begin{array}{c}56.00 \\
(48.46)^{\mathrm{b}}\end{array}$ \\
\hline T3 & $\begin{array}{l}\text { Two sprays with Hexaconazole } \\
\text { followed by two sprays with } \\
\text { P.F-4 }\end{array}$ & $\begin{array}{c}22.00 \\
(27.95)^{\mathrm{bcd}}\end{array}$ & $\begin{array}{c}28.53 \\
(32.27)^{\mathrm{c}}\end{array}$ & $\begin{array}{c}36.00 \\
(36.85)^{\mathrm{cd}}\end{array}$ & $\begin{array}{c}48.35 \\
(44.05)^{\mathrm{bcd}}\end{array}$ \\
\hline T4 & $\begin{array}{l}\text { Seedling dip with P.F-4 and two } \\
\text { sprays followed by two sprays } \\
\text { with Hexaconazole }\end{array}$ & $\begin{array}{c}16.00 \\
(23.55)^{\mathrm{e}}\end{array}$ & $\begin{array}{c}30.66 \\
(33.60)^{\mathrm{bc}}\end{array}$ & $\begin{array}{c}35.49 \\
(36.55)^{\mathrm{cd}}\end{array}$ & $\begin{array}{c}44.40 \\
(41.76)^{\mathrm{cd}}\end{array}$ \\
\hline T5 & $\begin{array}{ll}\text { Alternate sprays } & \text { with } \\
\text { Hexaconazole and P.F-4 } & \end{array}$ & $\begin{array}{c}17.00 \\
(24.32)^{\mathrm{de}}\end{array}$ & $\begin{array}{l}21.47 \\
(27.52)^{\mathrm{d}}\end{array}$ & $\begin{array}{c}30.00 \\
(33.17)^{\mathrm{d}}\end{array}$ & $\begin{array}{c}40.00 \\
(39.21)^{\mathrm{d}}\end{array}$ \\
\hline T6 & $\begin{array}{l}\text { Alternate sprays with P.F-4 and } \\
\text { Hexaconazole }\end{array}$ & $\begin{array}{l}20.00 \\
(26.49)^{\text {cde }}\end{array}$ & $\begin{array}{c}24.00 \\
(29.28)^{\mathrm{d}}\end{array}$ & $\begin{array}{l}33.45 \\
(35.30)^{\mathrm{cd}}\end{array}$ & $\begin{array}{l}52.22 \\
(46.28)^{\mathrm{bc}}\end{array}$ \\
\hline T7 & $\begin{array}{l}\text { Seedling dip with P.F-4 } \\
\text { followed by mixed spray of } \\
\text { Hexaconazole and P.F-4 }\end{array}$ & $\begin{array}{c}25.00 \\
(29.95)^{\mathrm{abc}}\end{array}$ & $\begin{array}{c}32.00 \\
(34.42)^{\mathrm{bc}}\end{array}$ & $\begin{array}{c}40.00 \\
(39.21)^{\mathrm{bc}}\end{array}$ & $\begin{array}{c}54.00 \\
(47.29)^{\mathrm{bc}}\end{array}$ \\
\hline T8 & Control & $\begin{array}{c}30.00 \\
(33.17)^{\mathrm{a}}\end{array}$ & $\begin{array}{c}40.00 \\
(39.21)^{\mathrm{a}}\end{array}$ & $\begin{array}{c}50.31 \\
(45.18)^{\mathrm{a}}\end{array}$ & $\begin{array}{c}67.83 \\
(55.53)^{\mathrm{a}}\end{array}$ \\
\hline & $\mathrm{CD}(0.05)$ & 3.965 & 2.736 & 4.357 & 5.534 \\
\hline & $\mathrm{CV}$ & 8.166 & 4.797 & 6.579 & 6.877 \\
\hline
\end{tabular}

Figures in parenthesis are arc sine values

Each treatment replicated thrice 
Table.2 Effect of the strategies of integration of fungicide and biocontrol agent on yield of rice

\begin{tabular}{|c|c|c|c|}
\hline \multirow[t]{2}{*}{ S.No } & \multirow[t]{2}{*}{ Treatments } & \multicolumn{2}{|c|}{ Rabi 2017-18 } \\
\hline & & $\begin{array}{l}\text { Grain yield } \\
\text { (t/ha) }\end{array}$ & $\begin{array}{l}\text { Straw yield } \\
\quad(\mathrm{t} / \mathrm{ha})\end{array}$ \\
\hline T1 & Hexaconazole & $6.70^{\mathrm{bc}}$ & $7.99^{b}$ \\
\hline $\mathbf{T 2}$ & Seedling dip with Pseudomonas fluorescens (P.F-4)and foliar spray & $6.41^{\mathrm{c}}$ & $7.76^{\mathrm{bc}}$ \\
\hline T3 & Two sprays with Hexaconazole followed by two sprays with P.F-4 & $7.37^{\mathrm{ab}}$ & $7.73^{\mathrm{bc}}$ \\
\hline T4 & $\begin{array}{l}\text { Seedling dip with P.F-4 and two sprays followed by two sprays } \\
\text { with Hexaconazole }\end{array}$ & $6.95^{a b c}$ & $8.53^{\mathrm{b}}$ \\
\hline T5 & Alternate sprays with Hexaconazole and P.F-4 & $7.56^{\mathrm{a}}$ & $10.26^{\mathrm{a}}$ \\
\hline T6 & Alternate sprays with P.F-4 and Hexaconazole & $6.92^{a b c}$ & $7.60^{\mathrm{bc}}$ \\
\hline T7 & $\begin{array}{l}\text { Seedling dip with P.F-4 followed by mixed spray of Hexaconazole } \\
\text { and P.F-4 }\end{array}$ & $6.87^{\mathrm{bc}}$ & $6.92^{c}$ \\
\hline T8 & Control & $5.44^{\mathrm{d}}$ & $5.76^{\mathrm{d}}$ \\
\hline & $\mathrm{CD}(0.05)$ & 0.769 & 1.041 \\
\hline & CV & 6.457 & 7.597 \\
\hline
\end{tabular}

The untreated control (T8) showed 50.31 PDI which was statistically at par with the treatment T2 (Seedling dip with Pseudomonas fluorescens (P.F-4) and foliar spray; 44.36 PDI). However, treatment T7 (Seedling dip with P.F-4 followed by mixed spray of Hexaconazole and P.F-4; 40.00 PDI) was statistically at par with $\mathrm{T} 2$ (Seedling dip with Pseudomonas fluorescens (P.F-4) and foliar spray; 44.36 PDI).

At 15 days after the fourth spraying, lowest per cent disease index (PDI) was observed in T5 (Alternate sprays with Hexaconazole and P.F-4; 40.00 PDI) which was statistically at par with T4 (Seedling dip with P.F-4 and two sprays followed by two sprays with Hexaconazole; 44.40 PDI) and T3 (Two sprays with Hexaconazole followed by two sprays with P.F4; 48.35 PDI).While in T8 (Untreated control) significantly higher stem rot disease was recorded with 67.83 PDI when compared with all other treatments. The stem rot PDI in T1, T6, T7, T2 treatments ranged from 49.93 to 56.00 which were at par with each other indicating their statistically equal efficacy in reducing the disease. The results in present investigation revealed that, the following integration strategies were statistically superior in managing the stem rot disease and also obtaining in good yields. Alternate sprays with Hexaconazole and P.F-4 (T5 with 40.00 PDI; $7.56 \mathrm{t} / \mathrm{ha}$ grain yield and $10.26 \mathrm{t} / \mathrm{ha}$ straw yield). Seedling dip with P.F-4 and two sprays followed by two sprays with Hexaconazole (T4 with $44.40 \mathrm{PDI}$, 6.95t/ha grain yield and $8.53 \mathrm{t}$ /ha straw yield). Two sprays with Hexaconazole followed by two sprays with P.F-4(T3 with 48.35PDI, 7.37t/ha grain yield and 7.73t/ha straw yield). In integrated management, the fungicide might have weakened the sclerotia making them more sensitive to antagonists. The present hypothesis is in agreement with the findings of Henis and Papavizas (1983) who also reported that sclerotia of $S$. rolfsii were weakened at sub-lethal concentrations of metham sodium and become sensitive to invasion and degradation by $T$. harzianum. However, the fungicide alone does not degrade fresh sclerotia. In such situation, the weakened or dead cells of pathogen might have served as enrichment medium for the multiplication of antagonists. Soil application of biocontrol agents have an edge over seed treatment, as these being natural soil inhabitants, they establish and multiply more quickly in soil (Vyas and Mathur, 2002). The present findings were supported by other workers accordingly the integration of biocontrol agent with 
compatible fungicide gave significantly higher disease control in several crops than obtained by either biocontrol agent (or) fungicide (Singh and Sinha 2007 and Daroga et al., 2007). Gopika and Jagadeeshwar (2017) conducted integrated management studies against stem rot of rice with twelve treatments. Of the twelve treatments combined soil application of butachlor (400 ppm) 8-10 days after inoculation by the pathogen followed by application of $T$. viride@10 $\mathrm{g} \mathrm{kg}^{-1}$ and P. fluorescens@10 ml $\mathrm{kg}^{-1}$ just at the appearance of the disease recorede the disease index (0.6), followed by spraying of propiconazole (100 ppm) with 1.2 (disease index) were found superior over other treatments in reducing the disease.

Hence, it is concluded in the present investigation, we are reporting that reduced disease severity due to integration strategies was reflected in the final yield of the crop. For successful management of rice stem rot disease under field condition integration of chemical and biological methods were essential as there were no resistant cultivars are available.

\section{References}

Directorate of Economics and Statistics. 2016. Area and production of Rice in India. 201516.

Elangovan, C and Gnanamanikum, S.S. 1992. Incidence of Pseudomonas fluorescens in rhizosphere of rice and their antagonism towards Sclerotium oryzae. Indian Phytopathology. 45 (3): 358-361.

Kumar, A., Ram Singh and Jalali, B.L. 2003. Management of stem rot of rice with resistance inducing chemicals and fungicides. Indian Phytopathology. 56 (3): 266-269.

Sakthivel, N., Sivamani., Anuratha, C. S.,
Savithiry, S., Gnanamanickam, S. S and Mahadevar, A. 1988. Beneficial bacteria for plant disease management. Advances in research on plant pathogenic bacteria based on the proceedings of the National Symposium on Phytobacteriology held at the University of Madras, Madras, India during March 14-15, 1986. 213-220.

Singh, R., Kumar, A. and Jalali, B. L., 2002. Variability, predisposing factors and management of stem rot caused by Sclerotium oryzae, An Overview. Annual Review of Plant Pathology. 1: 275-289.

Singh, R and Sinha, A.P. 2007. Management of sheath blight of rice with Pseudomonas fluorescens. Journal of Mycology and Plant Pathology. 37 (1): 18-21.

Standard evaluation system for rice (SES). 2013. International Rice Research Institute. $5^{\text {th }}$ edition. Phillipines.

Daroga, Singh., Singh, V.K., Gopal, Singh and Singh, U. S. 2007. Integrated management of sheath blight and sheath rot by using Trichoderma viride and validamycin in rice cv. Pusa Basmati-1. Progressive Agriculture. 7 (1/2): 181-182.

Gopika, K and Jagadeeshwar, R. 2017. Studies on disease incidence and efficacy of fungicides, herbicides and antagonists micro flora against stem rot of rice (Sclerotium oryzae) along with integrated management. Agriculture Update. 12(7): 2077-2087.

Henis, Y and Papavizas, G.C. 1983. Factors affecting germinability and susceptibility to attack of sclerotia of Sclerotium rolfsii by Trichoderma harzianum in field soil. Phytopathology. 3: 1469-1474.

Vyas, R.K and Mathur, K. 2002. Distribution of Trichoderma spp. in cumin rhizosphere and their potential in suppression of wilt. Indian Phytopathology. 55: 451-457.

\section{How to cite this article:}

Atla Ranga Rani, C.P.D. Rajan, R. Sarada Jayalakshmi Devi, V. Lakshmi Narayana Reddy and P. Sudhakar. 2018. Field Evaluation of the Strategies of Integration of Fungicides and Bio Control Agents for Efficient Management of Rice Stem Rot Disease. Int.J.Curr.Microbiol.App.Sci. 7(07): 3796-3800. doi: https://doi.org/10.20546/ijcmas.2018.707.440 